\title{
Foreign Bank Penetration, Resource Allocation and Economic Growth: Evidence from Emerging Economies
}

\author{
Ji Wu \\ Penn State University, Harrisburg, PA \\ Bang Nam Jeon \\ Drexel University, Philadelphia, PA \\ Alina C. Luca \\ International Monetary Fund, Washington, D.C.
}

\begin{abstract}
This paper examines the implications of foreign bank penetration on economic growth from the perspective of resource allocation in host countries. We use aggregate banking data, constructed from bank-level balance sheets and income statement information covering more than 1200 banks in the 35 emerging economies of Asia, Latin America and Eastern and Central Europe for the period from 1996 to 2003. By applying the pooled OLS and fixed-effects models, we present consistent evidence that the effect of gross fixed capital formation on output growth is higher in an economy with a more pronounced level of foreign bank penetration relative to an economy with a lower level of foreign bank penetration. This finding suggests that foreign banks play an important role in allocating capital in a more productive way, thus leading to a higher economic growth rate. One of the main policy implications of our findings in this paper is

\footnotetext{
*Corresponding address: Bang Nam Jeon: Professor of Economics and International Business, Bennett S. LeBow College of Business, Drexel University, Philadelphia PA 19104, U.S.A., Tel: (215) 895-2125, e-mail: jeonbana@drexel.edu. 
that foreign banks may serve as a channel in enhancing economic integration of emerging economies with advanced economies that are the home countries of foreign banks.

- JEL Classification: E44, F43, G21

- Key Words: foreign bank penetration, economic growth, resource allocation

\section{Introduction}

Since the early 1990s, foreign banks have significantly increased their presence and market share in emerging economies. The assessment of the impact of an increasing level of foreign bank penetration on emerging economies, both at the macroeconomic level and at the individual bank level, has been an important, yet controversial, issue for both academicians and policy makers.

This paper examines the implication of foreign bank penetration on resource allocation and economic growth in host emerging economies. Foreign bank penetration, bringing both benefits and concerns, may affect the economic growth of host countries both directly and indirectly. Direct benefits may arise when foreign banks bring additional capital into the host countries, seek profitable uses of these funds, and exert effective corporate control for productive use of loanable funds. By doing this, foreign banks may directly boost the efficiency of resource allocation, leading to an accelerated economic growth in the host country. At the same time, foreign bank penetration could achieve a better resource allocation indirectly, by intensifying competition in the banking market and stimulating domestic banks to improve their operational efficiency in financial service. (Demirguc-Kunt et al., 1998). Quite a few studies have presented evidence that foreign bank penetration may accelerate economic growth by adding more competition and inducing efficiency gains in the banking sector, which is an indirect channel of a foreign bank's contribution to economics growth in the host country. So far, however, not much empirical evidence has been reported in the literature to support the hypothesis that a higher foreign bank penetration is directly associated with host countries' economic growth through an efficient resource allocation, especially for capital.

We investigate whether the direct effect of foreign banks on resource allocation is relevant for economic growth or not, after properly controlling for another possible effect through changes in banking sector. We specifically examine whether 
the effects of capital and labor on economic growth would be higher in economies with more pronounced foreign bank participation than in economies with lower level of foreign bank penetration, after controlling for competitiveness and its interaction with capital and labor. If the proposition is confirmed, it would contribute to the literature on the direct effect of foreign bank penetration on economic growth, especially the perspective of resource allocation.

Our finding suggests that foreign banks seek good borrowers and have resources allocated directly to the most productive sectors of host economies. It is worthwhile to note that, following Demirguc-Kunt et al. (1998), the difference between the terms "direct" and "indirect" lies in that, foreign banks "directly" search and find good borrowers, and "indirectly" drive domestic banks to compete with their competitors, domestic and foreign, more actively. In both cases, resources would be better allocated and output would be higher than in the case of economies with less foreign bank presence. The implication is that, besides stimulating more competition in the banking sector, an increased foreign bank penetration has additional direct effects on the allocation of production resources in host countries.

This paper presents evidence that higher foreign bank penetration enhances economic growth through the channel of resource allocation. The effect of capital accumulation on output growth is higher in the economies where foreign bank presence is more pronounced, which is interpreted to be consistent with the hypothesis that foreign banks could help capital to be better allocated in more productive ways and into the most productive sectors. The higher effects of capital growth on output growth in the economies with high foreign bank penetration remain significant even after we control for the effects of higher competition in the banking sector. However, no different effects of labor on output growth are found in the economies with different levels of foreign bank penetration.

The remainder of this paper is organized as follows. Section II reviews briefly the related literature. Sector III describes the data used in the study and reports their descriptive statistics. Section IV describes the empirical model and reports the empirical results. Section V concludes.

\section{Literature Review: the Role of Foreign Banks on Economic Growth}

It has been intensively debated whether or not financial development plays a 
significant role in economic growth. ${ }^{1}$ The financial system plays a role in economic growth by allocating capital, monitoring borrowers, exerting corporate control, facilitating risk management, among others. ${ }^{2}$ The level of financial development is found to be positively associated with long-run economic growth. (For example, see Goldsmith (1969), King and Levine (1993a and 1993b), De Gregorio and Guidotti (1995), Rajan and Zingales (1998), Levine et al. (2000), and Beck et al. (2004)).

However, the implication that foreign bank entry positively affects the host country's economic growth is still far from conclusive. There are only a limited number of papers on the direct linkage between foreign bank entry and economic growth in host economies. The direct impact of foreign bank penetration could be arisen from bringing additional capital into the host economies, energetically seeking the most profitable use of their funds, and facilitating an effective risk management. Demirguc-Kunt et al. (1998) find no evidence that foreign banks directly influence long-run economic growth, but do find that the increased participation of foreign banks in the host country banking market tends to lower the probability of a banking crisis. Bayraktar and Wang (2006) find some evidence on both direct and indirect links between the foreign bank presence and economic growth by observing 28 developed and developing countries. ${ }^{3}$

In contrast to few papers that examine the direct impact of the foreign bank presence on economic growth, more works have been conducted and have found that foreign banks could indirectly foster higher economic growth by adding competition and improving the efficiency in the banking sector. Claessens et al. (2001) find evidence that an increasing foreign bank presence is associated with lower profits and costs in the domestic banking sector, which reflects higher

\footnotetext{
${ }^{1}$ Some influential economists believe that finance is a relatively unimportant factor in economic development. For example, Lucas (1988) said the relationship between financial and economic development is "badly over-stressed".

${ }^{2}$ The "financial system" in Levine (1996) includes not only banks, but a broad mix of financial instruments, markets and institutions.

${ }^{3}$ Capital and labor are excluded in their regression model since the cost of capital (then the capital accumulation) is assumed to be affected by financial development and labor is assumed to play no special role. However, economies with comparably equivalent financial development are still observed with substantial differences in the cost of capital. The cost of capital could be more affected by monetary policy than the development of financial sector. In our paper, we include some measures of the development in financial markets, and capital accumulation and labor are still fundamental production inputs that affect economic growth. The mixed pool of both developed and developing countries also only partially helps to answer the question whether and how foreign bank penetration could affect economic growth for emerging and relatively poor economies.
} 
competition and efficiency stimulated by the entry of foreign banks. DemirgucKunt et al. (1998) find that foreign bank penetration tends to render the domestic banking sector more efficient, and economic growth is positively associated with the efficiency of the banking industry. Martinez Peria et al. (2004) also find that increased foreign bank entry is associated with cost reduction throughout the banking system.

It is not yet clear whether a higher level of foreign bank penetration has a positive or negative effect on firms' access to credit. Those against the entry of foreign banks into host countries argue that foreign banks would tend to "cherry pick" the most profitable borrowers, leaving some firms unattended, especially the small and medium sized firms who are likely to be informationally opaque. If this argument is justified, a high level of foreign bank penetration may hurt the economic growth of host countries since small and medium sized firms represent usually the largest group of total enterprises and hire a large share of employees. Berger et al. (2001) find that foreign banks avoid lending to informationally opaque firms.

Foreign banks' different behavior in providing loans to local firms, compared to domestic banks, has been documented. For example, Clarke et al. (2001) find that foreign bank penetration improves financing conditions for enterprises of all sizes, although this process seems to benefit larger firms more. Clarke et al. (2002) find that foreign banks, in a sample of four Latin American countries, generally lend less to small businesses than do private domestic banks, but the difference is primarily driven by the behavior of small foreign banks, and that, in two countries out of the four, large foreign banks lend more to small businesses than large domestic banks do. Detragiache et al. (2006) develop a theoretical model and find empirical evidence in 89 poor countries to support the hypothesis that credit to the private sector is lower in countries with more foreign bank participation when foreign banks depend on hard data for loan decisions. As a country case study, Gormley (2007) uses data from India and finds that foreign banks finance only a small set of very profitable firms. As a firm-level study, Giannetti and Ongena (2007) find that although foreign bank lending stimulates the growth of firm sales and assets of all firms, the effect is weaker for small firms. The debate on this important issue has not yet been settled, which demonstrates a pressing need for identifying and estimating the role of foreign banks on resource allocation and economic growth. 


\section{Data}

We use annual observations of the country level data in our analysis. Our data set covers a total of 35 emerging and developing economies from three regionsAsia, Latin America and Eastern and Central Europe-for the period from 1996 to $2003 .{ }^{4}$ We obtain the country-level banking data by aggregating individual banklevel data over year and country, which are obtained from Bureau van Dijk's BankScope database. ${ }^{5}$ Our bank-level series are composed of 6844 yearly observations, covering 1273 banks in the above-mentioned 35 economies during the years from 1996 to 2003, a period when foreign banks increasingly penetrated into emerging economies. We select only commercial banks for the dataset to reduce the number of possibly biased results arising from the varying nature and business scope among a variety of banks which both exhibit different objectives and conduct businesses in different specializations.

\section{A. Bank Ownership and Foreign Bank Penetration}

We identify a bank as "foreign" if more than 50 percent of the ownership of capital of the bank is held by foreign individuals, firms (including banks), or international organizations in every year from 1996 through 2003. ${ }^{6}$ Departing from the identification found in Arena et al. (2006), we do not only classify the banks from industrialized OECD countries as "foreign", but also treat any bank whose owner is not from the host country as "foreign". As BankScope records the ownership of banks only for the most recent year, we resort to various other sources to pin down the ownership status of the banks for every year during our sample period from 1996 to 2003. For the complete identification of the bank

\footnotetext{
${ }^{4}$ The countries include: Albania, Belarus, Bulgaria, Croatia, Czech Republic, Estonia, Hungary, Latvia, Lithuania, Macedonia, Moldova, Poland, Romania, Slovak Republic, Slovenia, Ukraine, Argentina, Bolivia, Brazil, Chile, Colombia, Ecuador, Mexico, Paraguay, Peru, Uruguay, Venezuela, Hong Kong SAR, India, Indonesia, Korea, Malaysia, Philippines, Singapore, and Thailand.

${ }^{5} \mathrm{BankScope}$ is the most comprehensive database of individual banks in emerging and developing countries, and covers on average more than 90 percent of the total banking assets of each country. (For more information on its coverage, see, for example, Claessens et al. (2001)). An additional advantage of using BankScope is that data are standardized, having been adjusted for differences in accounting and reporting standards across countries. We also use alternative data for foreign bank penetration from Micco et al. (2004) in our robustness checks to check the quality of the data that we use. Our foreign bank penetration data series, constructed based on BankScope, is found to be highly correlated with the one in Micco et al. (2004).

${ }^{6}$ In our dataset, most of the foreign banks are foreign-owned subsidiaries. Some banks are owned by international organizations, such as European Bank of Reconstruction and Development (EBRD).
} 
ownership, we take following steps. First, we check the brief overview of the bank recorded in BankScope, which identifies the ownership for only some banks. Second, we review the bank's profile of its historical evolution from its website. If a bank has experienced a change in its ownership, it is usually highlighted in its profile. Third, we depend on another comprehensive database, SDC Platinum, for mergers and acquisitions (M\&A) information. Finally, if we are still unable to identify the ownership of the bank after following these aforementioned steps, we resort to various other information sources, such as banks' annual reports, central banks' publications and news reports on changes in the bank ownership available on the Internet.

After individual banks' ownerships are identified, we aggregate selected variables to their country level. For example, we aggregate the assets of all banks in a country to obtain the banking sector total assets. The levels of foreign bank penetration by year and country are measured by aggregating total assets of individual foreign banks for the year-country observations and dividing the sum by the total assets of the banking sector each year for each country. This measure indicates the degree of foreign bank dominance in the host country banking market. The construction for the measurement of the market share held by stateowned domestic banks follows a similar way.

Our estimation of the foreign bank penetration level, based on total assets, varies among the sample countries. On average during our sample period, the lowest three countries are India, Thailand and Ecuador (only $0.76 \%, 5.51 \%$ and $5.73 \%$, respectively), and the highest three are Albania, Hong Kong and Hungary (90.94\%, $89.16 \%$ and $76.28 \%$, respectively). Figure 1 depicts the level and trend of foreign bank penetration in selected countries in our sample. ${ }^{7}$ Overall, the Eastern and Central European countries are shown to have the highest average foreign bank penetration level (43.76\%), while the Asian countries have the lowest level of foreign bank penetration (19.69\%). To check robustness, we also use two alternative indicators for the level of foreign bank penetration using loans, instead of total assets. We aggregate the loans made by individual foreign banks and then divide them by the total loans of the banking sector in each country each year. Another alternative measure of the foreign bank penetration level is one borrowed from Micco et al. (2004), which is also calculated based on bank assets but in a

${ }^{7}$ The graphs for other countries in our sample are available from the authors. 


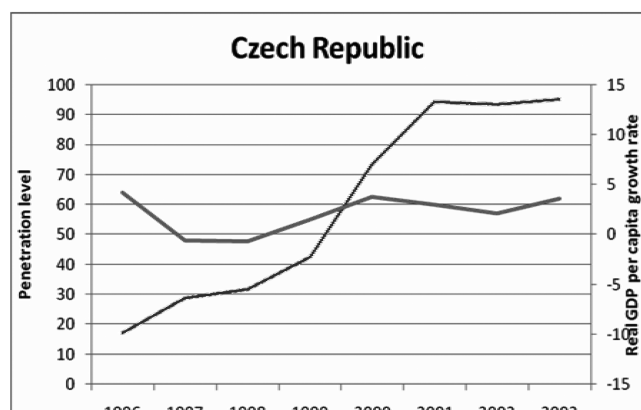

$\begin{array}{llllllll}1996 & 1997 & 1998 & 1999 & 2000 & 2001 & 2002 & 2003\end{array}$

— penetration level (in terms of total assets) —Real GDP per capita growth rate (\%)
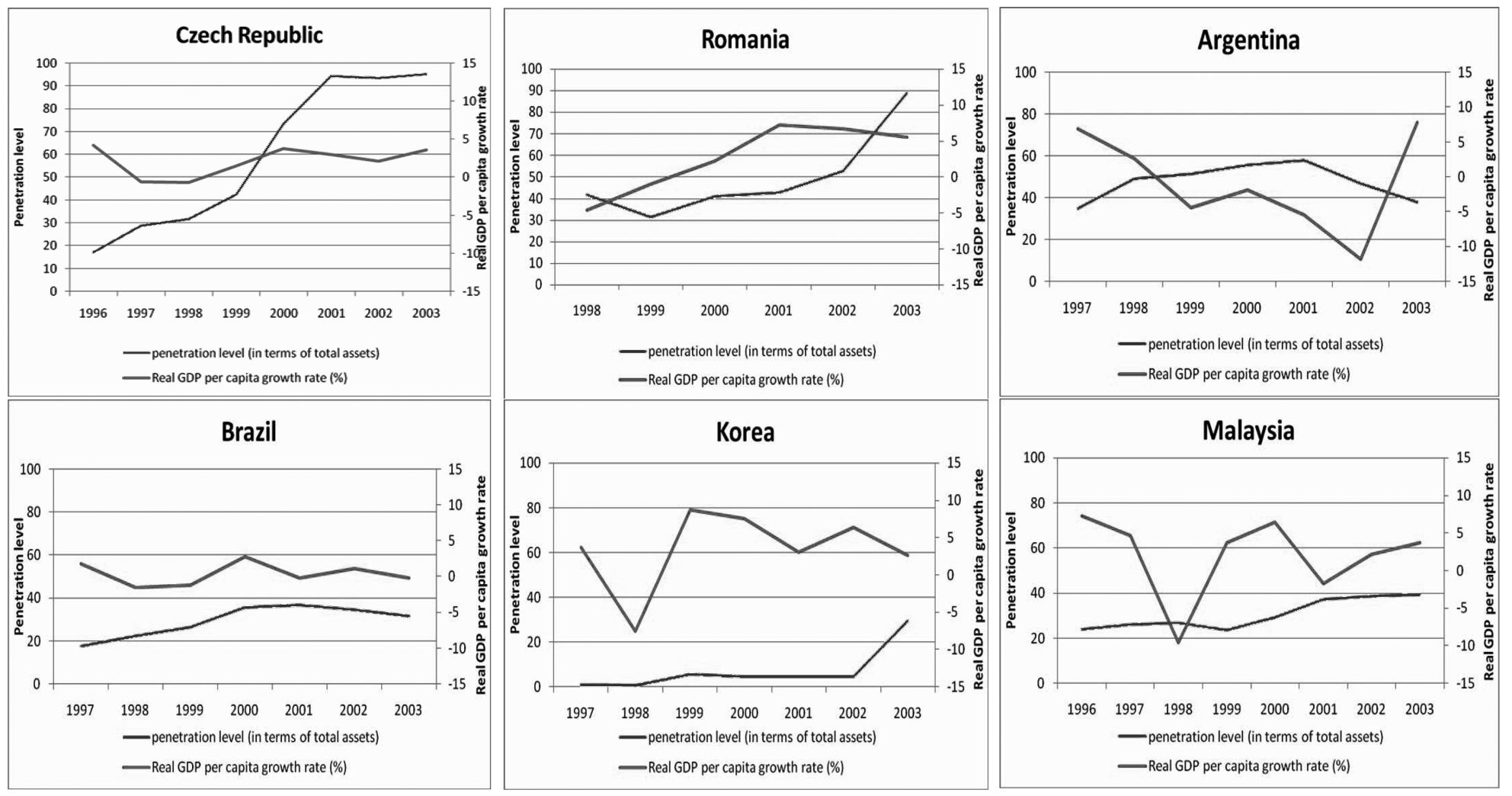

$\begin{array}{lllllll}1997 & 1998 & 1999 & 2000 & 2001 & 2002 & 2003\end{array}$

— penetration level (in terms of total assets) —Real GDP per capita growth rate (\%)

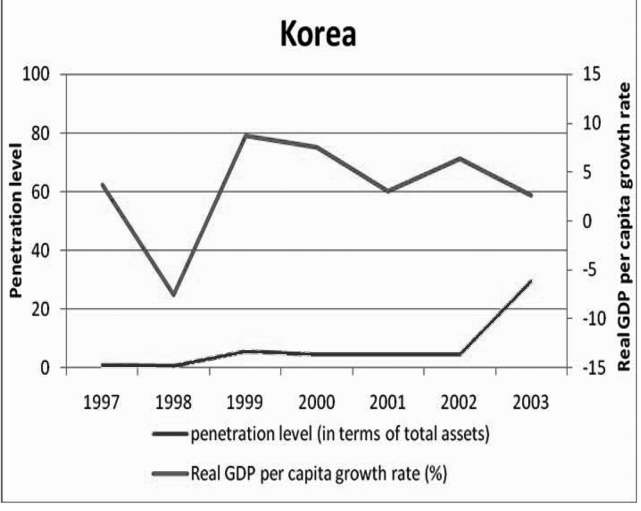

Malaysia

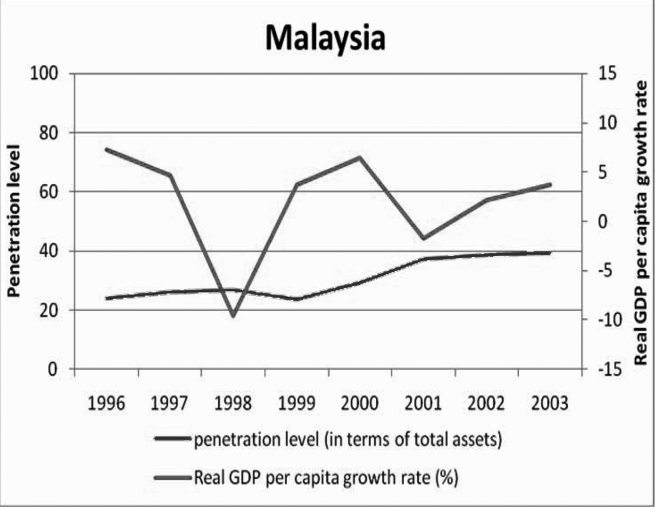

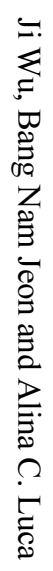


more sophisticated way. ${ }^{8}$ All three measures of the foreign bank penetration level are highly correlated.

\section{B. Domestic Credit and Banking Competition}

We calculate the ratios of domestic credit made by the banking sector over GDP, and use them as an indicator of the relative importance of the banking sector, or the degree of financial deepening, in a sample country in a given year. Another proxy that could be used is the ratio of domestic credit to the private sector only over GDP. However, these two proxies are highly correlated. Following Levine and Zervos (1998), we also use the stock market turnover rate as a proxy for the degree of stock market development. It has been reported in the growth literature that stock markets play a favorable role for economic growth. The stock market turnover rates data are borrowed from Beck et al. (2000).

In order to control the indirect effects including the competition effect of domestic and foreign banks on economic growth, we measure the competitiveness of the banking sector by calculating the ratio of the weighted average net interest revenue to average assets for all banks in a given country and year. The rationale for the banking competition measurement is that the relative magnitude of net interest revenue would be lower in a more competitive banking market. A higher value in net interest revenues over average assets indicates a weaker level of competition among banks. The level of concentration in the banking sector is also calculated to measure the degree of the competition among banks, since it is expected that competition would be undermined in a more concentrated market. We obtain the banking concentration indicator by calculating the ratio of the sum of total assets of the three largest banks to the banking sector total assets in a given country and year. These two measures are positively, but not very highly, correlated.

\footnotetext{
${ }^{8}$ Micco et al. (2004) measure the foreign ownership in an individual bank by using the actual fraction of shares owned by foreign shareholders, then calculate the national foreign bank penetration level by multiplying the foreign ownership by the total assets of the bank, summing up all the assets owned by foreign shareholders and dividing it by the total assets in the banking sector. For example, in an hypothetical economy where there is only one bank controlled by foreign shareholders, if the foreign shareholders own $60 \%$ of assets in that bank, Micco et al (2004) measure the foreign ownership in that bank is 0.6 . If the assets of that bank is $\$ 1$ billion, and the total assets in banking sector is $\$ 10$ billion, Micco et al (2004) would measure the national foreign bank penetration level is $0.6 * 1 / 10=6 \%$.
} 


\section{Capital and Labor}

Capital and labor are two fundamental resources that affect economic growth in our model. Capital input is measured by the gross fixed capital formation, equivalent to gross domestic fixed investment, which includes plants, machinery, and equipment purchases; land improvements; and the construction of infrastructure. The growth rate of fixed capital formation is expected to be positively related to the growth rate of output. The series of the gross fixed capital formation data for the 35 emerging economies for our sample period are obtained from the World Development Indicator (WDI) database. Labor input is measured as the employed labor force. We first collect the data of labor force from the WDI and unemployment rates from the International Financial Statistics (IFS) for each of the 35 countries. We obtain the number of employed labor force using labor force*( 1 unemployment rate), and then calculate the growth rate of the employed labor force in a given country and year. It is not necessary that the growth rate of employed labor be positively correlated with the growth rate of output since there may be the substitution effect between capital and labor as the industry structure in the host emerging countries becomes more capital- and knowledge-intensive.

\section{Control Variables}

It has been reported in the growth literature that the initial development level is an important factor to determine the pattern of catching up with advanced economies. We use normalized GDP per capita in 1995 (in terms of constant US dollar values) as the initial economic development indicator. A country in a lower initial development stage may grow faster than the countries in a higher level development stage, which is consistent with a converging pattern of economic growth across countries. We also include inflation and foreign exchange depreciation rates in the set of explanatory variables by following the empirical growth literature as being correlated with economic growth across countries (Beck et al. (2000)). Since our data covers a relatively a short time period, we do not include the specific variables for the purpose of controlling innovation and the technology advancement by assuming that they would not change substantially during this short time period. ${ }^{9}$

\section{E. Descriptive Statistics and Correlation Coefficient Matrix}

The descriptive statistics are reported in Table 1. These statistics reveal some 
Table 1. Summary Descriptive Statistics

\begin{tabular}{|c|c|c|c|c|c|c|}
\hline & Obs & Mean & Standard Deviation & Median & Min & Max \\
\hline $\begin{array}{l}\text { Growth rate of real GDP per } \\
\text { capita }\end{array}$ & 69 & 2.503 & 3.328 & 2.312 & -5.480 & 10.343 \\
\hline $\begin{array}{l}\text { Growth rate of fixed capital } \\
\text { formation }\end{array}$ & 67 & 4.303 & 10.170 & 3.866 & -22.697 & 39.272 \\
\hline $\begin{array}{l}\text { Growth rate of employed } \\
\text { labor }\end{array}$ & 67 & .976 & 2.475 & .909 & -5.050 & 14.047 \\
\hline Inflation & 67 & 9.984 & 12.603 & 7.079 & -2.752 & 75.173 \\
\hline $\begin{array}{l}\text { Foreign exchange deprecia- } \\
\text { tion }\end{array}$ & 67 & 10.590 & 16.393 & 6.377 & -8.451 & 84.115 \\
\hline Domestic credit / GDP & 69 & 54.968 & 41.192 & 46.186 & 13.475 & 207.357 \\
\hline $\begin{array}{l}\text { Credit to private sector / } \\
\text { GDP }\end{array}$ & 69 & 43.973 & 43.001 & 27.233 & 3.841 & 198.489 \\
\hline Stock market turnover rate & 65 & 56.282 & 92.960 & 29.553 & .631 & 492.944 \\
\hline $\begin{array}{l}\text { Net interest revenue/aver- } \\
\text { age assets (all banks)-Bank- } \\
\text { ing competition } 1\end{array}$ & 69 & 4.708 & 2.711 & 4.180 & -1.050 & 14.479 \\
\hline $\begin{array}{l}\text { Net interest revenue/aver- } \\
\text { age assets (domestic banks } \\
\text { only)--Banking competi- } \\
\text { tion } 2\end{array}$ & 68 & 4.689 & 2.985 & 4.455 & -2.595 & 14.702 \\
\hline $\begin{array}{l}\text { Non-interest expenses/aver- } \\
\text { age assets (all banks)-Bank- } \\
\text { ing competition } 3\end{array}$ & 69 & 6.929 & 4.005 & 5.718 & 1.017 & 21.415 \\
\hline Banking concentration level & 69 & 56.363 & 15.797 & 52.765 & 32.278 & 97.875 \\
\hline $\begin{array}{l}\text { Foreign bank penetration } \\
\text { level (in terms of total } \\
\text { assets) }\end{array}$ & 69 & 36.916 & 29.214 & 34.143 & 0 & 100 \\
\hline $\begin{array}{l}\text { Foreign bank penetration } \\
\text { level (in terms of loans) }\end{array}$ & 69 & 37.555 & 30.109 & 34.480 & 0 & 100 \\
\hline $\begin{array}{l}\text { State-owned banks market } \\
\text { share }\end{array}$ & 69 & 21.709 & 22.036 & 13.584 & 0 & 91.243 \\
\hline
\end{tabular}

Notes: We complied thecountry-level banking data by aggregating individual bank-level data over year and country, which are obtained from Bureau van Dijk's BankScope database. Our bank-level series are composed of 6844 yearly observations, covering 1273 banks in the above-mentioned 35 economies during the years from 1996 to 2003. The banking concentration level is measured by the ratio of the assets in the largest three to total banking sector assets. The foreign bank penetration level (in terms of total assets) is the ratio of foreign bank assets over total banking sector assets. The foreign bank penetration level (in terms of loans) is the ratio of loans from foreign banks to total banking sector loans. The market share of state-owned banks is measured by the ratio of state-owned bank assets over the banking sector total assets. 
important characteristics of the banking sector and macroeconomy of our sample emerging economies. For example, emerging economies are characterized by relatively large variations of their growth rates (the standard deviation is above 3.33 percent and larger than the mean growth rate of 2.50 percent), high but variant capital growth rates (mean of 4.30 percent and standard deviation of 10.17),${ }^{10}$ and a slower growth rate of employed labor force ( 0.98 percent). Inflation and home currency depreciation rates are relatively high in the sample countries (both approximately 10 percent). In the banking sector, the foreign bank penetration rate is around 37 percent on the average (36.9 percent in terms of total assets and 37.6 percent in terms of loans), and state-owned banks retain a relatively high market share (21.71 percent). The dependence on banks for financing varies substantially across countries, ranging from the lowest in Lithuania (13.47 percent) and the highest in Malaysia (207.35 percent).

The correlation coefficients among the main variables are reported in Table 2. The growth rate of fixed capital is positively correlated with the growth rate of real GDP per capita, which suggests that the accumulated capital stock is an important source of economic growth for emerging economies, a la the Solow growth model. The growth rate of employed labor is shown to be negatively correlated with output growth and the correlation is not statistically significant. This is not very surprising if the economic growth of emerging economies depends more on the growth of capital stock, which substitutes less productive labor in the production process. The foreign bank penetration level is positively but weakly correlated with output growth, which seems consistent with the difficulties in the literature to find direct association between foreign bank penetration and economic growth. Although the foreign bank penetration level is negatively correlated with the measurement of (an inverse of) bank competition, which is consistent with the general finding that foreign banks stimulate more competition in the banking market, the correlation coefficient is not statistically significant. ${ }^{11}$

\footnotetext{
${ }^{9}$ We have also controlled for other unobserved bank effects, such as average liquidity, capitalization, riskiness (measured by the ratio of loan loss provision to total loans), and macroeconomic effects, such as trade openness. We find that most of these variables do not produce statistically significant coefficients and they do not affect our main results significantly. In addition, by using fixed-effect estimation, we have also controlled for time-invariant unobserved effects, such as the legal origin or other various institutional factors.

${ }^{10}$ Albania is observed to have the highest average growth rate of fixed capital, while Colombia is observed to have the largest contraction in fixed capital.

${ }^{11}$ The correlation between alternative foreign bank penetration and competitiveness measures is also negative but insignificant. Accordingly, we do not include an interaction term between the two measures in our regression.
} 
Table 2. Correlation Coefficients

\begin{tabular}{|c|c|c|c|c|c|c|c|c|c|c|}
\hline & 1 & 2 & 3 & 4 & 5 & 6 & 7 & 8 & 9 & 10 \\
\hline 1. Growth rate of GDP per capita & 1.000 & & & & & & & & & \\
\hline $\begin{array}{l}\text { 2. Growth rate of fixed capital } \\
\text { formation }\end{array}$ & $0.709^{* * *}$ & 1.000 & & & & & & & & \\
\hline 3. Growth rate of labor & -0.149 & -0.005 & 1.000 & & & & & & & \\
\hline 4. Inflation & -0.086 & 0.034 & $-0.225^{*}$ & 1.000 & & & & & & \\
\hline 5. Foreign exchange depreciation & $-0.201^{*}$ & -0.141 & -0.219 & $0.915^{* * *}$ & 1.000 & & & & & \\
\hline 6. Domestic credit / GDP & -0.152 & $-0.315^{* * *}$ & 0.175 & -0.187 & -0.136 & 1.000 & & & & \\
\hline 7. Stock market turnover rate & 0.043 & -0.058 & -0.093 & -0.117 & -0.101 & 0.045 & 1.000 & & & \\
\hline $\begin{array}{l}\text { 8. Net interest revenue / average } \\
\text { assets - the inverse of banking } \\
\text { competition }\end{array}$ & $-0.225^{*}$ & 0.103 & -0.048 & $0.205^{*}$ & $0.232^{*}$ & $-0.505^{* * *}$ & -0.097 & 1.000 & & \\
\hline 9. Foreign bank penetration level & 0.0515 & 0.009 & -0.017 & $-0.207^{*}$ & $-0.282^{* *}$ & -0.063 & -0.090 & -0.033 & 1.000 & \\
\hline 10. State-owned banks share & -0.001 & 0.006 & -0.192 & $0.237^{*}$ & $0.222^{*}$ & 0.056 & 0.124 & $-0.324^{* * *}$ & $-0.540^{* * *}$ & 1.000 \\
\hline
\end{tabular}

Notes: ${ }^{* * *}$ represents the $1 \%$ significance level, ${ }^{* *}$ the $5 \%$ significance level and ${ }^{*}$ the $10 \%$ significance level 
All variables are then averaged over the years 1996-1999 and 2000-2003 to take into account economic growth as a long-run phenomenon, as is widely practiced in this literature. ${ }^{12}$ (For example, see King and Levin (1993) and Levin et al. (2000)) Therefore, every country has two observations, respectively measuring the mean value of the variables of interest over the periods both before and after year 2000 . Applying this structure of data, we interpret the results of our estimation as a longrun relationship between foreign bank penetration and economic growth in the emerging economies since the mid-1990s when foreign banks started to enter emerging markets aggressively.

\section{The Methodology and Estimation Results}

In this section we examine whether or not foreign bank penetration affects economic growth through the channel of resource allocation in emerging economies. After controlling for the competitiveness of the banking sector, which are expected to generate the indirect effect of foreign bank penetration on economic growth, if we still find evidence that the effect of the two production factors of capital and labor on output growth is higher in countries where the foreign bank presence is more pronounced, it can be interpreted as the evidence of "the direct effect" of foreign banks on economic growth defined by DemirgucKunt et al. (1998). In other words, foreign banks not only foster more competition in the banking market, but also generate additional and relevant effects of having resources better allocated, all contributing to economic growth of their host countries.

\section{A. The Methodology}

We establish two different models for our study of the effect of foreign bank penetration on economic growth-the pooled OLS model and the fixed-effects estimation model. The pooled OLS model is specified as follows:

$$
\begin{aligned}
& \operatorname{gr}(\text { GDP per capita })_{i, t}=\beta_{0}+\beta_{1} \cdot \text { gr }(\text { fixed capital })_{i, t}+\beta_{2} \cdot \operatorname{gr}(\text { labor })_{i, t} \\
& +\alpha_{0} \cdot \text { penetration }_{i, t}+\alpha_{1} \cdot \text { penetration }_{i, t}{ }^{*} \text { gr }\left({\text { fixed capital })_{i, t}}\right.
\end{aligned}
$$

\footnotetext{
${ }^{12}$ It is common practice in the growth literature to use multi-year averages to capture long-term effects. One could argue that averages calculated over longer periods of time would be more appropriate; however, lack of longer time series for emerging markets in general, and for the study of foreign bank penetration (a more recent phenomenon) in particular, prevents us from doing that.
} 
$+\alpha_{2} \cdot$ penetration $_{i, t}{ }^{*} \operatorname{gr}(\text { labor })_{i, t}+\eta \cdot$ inital developmenti +

$\lambda \cdot$ financial development $_{i, t}+v \cdot$ other control variables $+\varepsilon_{i, t}$

The model of the fixed-effects estimation is specified as:

$$
\begin{aligned}
\operatorname{gr}(\text { GDP per capita })_{i, t}= & \beta_{0}+\beta_{1} \cdot \text { gr }\left(\text { fixed capital }_{i, t}+\beta_{2} \cdot \operatorname{gr}(\text { labor })_{i, t}\right. \\
& +\alpha_{0} \cdot \text { penetration }_{i, t}+\alpha_{1} \cdot \text { penetration }_{i, t} * \text { gr }\left(\text { fixed capital }_{i, t}\right. \\
& +\alpha_{2} \cdot \text { penetration }_{i, t} * \text { gr }(\text { labor })_{i, t}+\lambda \cdot \text { financial development }_{i, t} \\
& +v \cdot \text { other control variables }+f_{i}+\varepsilon_{i, t}
\end{aligned}
$$

Different assumptions are applied to the two models specified above. In the pooled OLS model, for the purpose of maintaining statistical consistency, contemporaneous exogeneity is assumed for the set of the explanatory variables, so that the error term $\varepsilon_{i, t}$ is not correlated with the regressors during the concurrent period. We also assume that there is no time-constant fixed effect in each country, or that this fixed effect is not correlated with the regressors. This assumption is relaxed in the fixed-effects model estimation by allowing for the fixed country effect, $f_{i}$, and we assume that $f_{i}$ could be correlated with the independent variables. In contrast to the assumption of contemporaneous exogeneity in the pooled OLS model, strict exogeneity for the set of explanatory variables is assumed in the fixed effects model, so that the error term $\varepsilon_{i, t}$ is not correlated with regressors for all periods. This might be a strong assumption since there could be feedback from the GDP growth rate for the period $t$ to the regressors for the period $t+1$. However, we confirm that the lagged values of the growth rate of GDP per capita is only weakly and statistically insignificantly correlated with the regressors for the following period, which is interpreted as evidence against any important feedback and concerns for possible simultaneity biases.

In both models, the dependent variable is the growth rate of real GDP per capita. The key production inputs, affecting economic growth in the models, are capital and labor. The input of capital is represented by gr(fixed capital $)_{i, t}$, the growth rate of gross fixed capital formation. Labor input is represented by $\operatorname{gr}(\text { labor })_{i, t}$, the growth rate of employed labor force. Following the finance-growth nexus literature, we include several financial development variables in the explanatory variables to examine whether or not financial development is a relevant factor for economic growth. domcredit $t_{i, t}$ is the ratio of total domestic credit made by the banking sector over GDP, which serves as an indicator of the size of banking in a 
financial structure or the degree of financial deepening. smturnover $r_{i, t}$ is the stock market turnover rate, which measures the development of alternative financial markets. intasall $i, t$ is the ratio of the weighted average net interest revenue to the average assets for all banks in a given country and year, which proxies the competitiveness of the banking sector. The higher the value of intasall $l_{i, t}$, the lower the competition in the banking sector. We also include the variable $s b s t a_{i, t}$, the assets held by domestic state-owned banks divided by the banking sector total assets, to examine the relevance of state-owned banks with GDP growth. In the pooled OLS model, we include the variable, inidevelopment ${ }_{i}$, to control the initial level of economic development, which is a constant value of real GDP per capita in year 1995 in each of the 35 emerging economies which we study. Other macroeconomic control variables include the inflation rate, inflation $_{i, t}$, and the home currency depreciation rate, depreciation ${ }_{i, t}$.

As discussed earlier, we use the variable, peneta $_{i, t}$, as the measure of the level of foreign bank penetration from the perspective of total assets held by foreign banks in a given country and year. We then introduce the interaction variables of the foreign bank penetration variable with production inputs, $g r\left(\text { fixed }_{\text {capital }}\right)_{i, t}$ and gr(labor $)_{i, t}$. The positive coefficients on the interaction variables, peneta $_{i, t}{ }^{*}$ gr(fixed capital $_{i, t}$ and peneta $_{i, t}{ }^{*}$ gr(labor $)_{i, t}$, would suggest that in an economy characterized by a higher level of foreign bank penetration, capital and labor are allocated in more productive ways, making contributions of the production resources to economic growth even higher.

\section{B. The Empirical Results}

We conduct the estimation of eq. (1) and (2) using the pooled OLS and the fixed-effects regression, respectively, to examine whether or not foreign banks are beneficial for economic growth through the channel of resource allocation. The benchmark estimation results with alternative specifications are reported in Table 3. Since we use averaged annual data over a 4-year time span, our results will be interpreted in the context of a long-run relationship between foreign bank penetration, resource allocation and economic growth. Before we discuss the main results on the impact of foreign bank penetration on economic growth, we go over the estimated coefficients on other variables including control variables quickly.

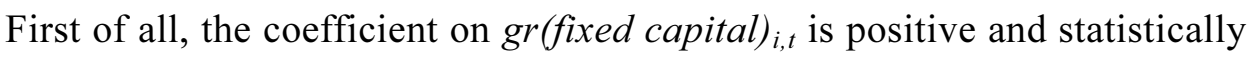
significant, implying that a higher growth rate of fixed capital accumulation is associated with a higher rate of economic growth, which is consistent with a main 
Table 3. Estimation Results on Foreign Bank Penetration, Banking Competition and Resource Allocation

\begin{tabular}{|c|c|c|c|c|c|c|}
\hline \multicolumn{7}{|c|}{ Dependent Variable: $\operatorname{gr}(\text { GDP per capita })_{i, t}$} \\
\hline & \multicolumn{3}{|c|}{ Pooled OLS } & \multicolumn{3}{|c|}{ Fixed-effect Estimation } \\
\hline & (1) & (2) & (3) & (4) & (5) & (6) \\
\hline $\operatorname{gr}\left(\right.$ fixed capital $_{i, t}$ & $\begin{array}{l}.1879^{* * *} \\
(.0351)\end{array}$ & $\begin{array}{l}.2439^{* * *} \\
(.0331)\end{array}$ & $\begin{array}{l}.2465^{* * *} \\
(.0333)\end{array}$ & $\begin{array}{l}.1188^{* * *} \\
(.0324)\end{array}$ & $\begin{array}{l}.1659^{* *} \\
(.0739)\end{array}$ & $\begin{array}{l}.2239^{* * *} \\
(.0540)\end{array}$ \\
\hline $\operatorname{gr}(\text { labor })_{i, t}$ & $\begin{array}{l}-.2921^{* * *} \\
(.0535)\end{array}$ & $\begin{array}{l}-.1520 \\
(.2166)\end{array}$ & $\begin{array}{l}-.1132 \\
(.2845)\end{array}$ & $\begin{array}{l}.2083 \\
(.2575)\end{array}$ & $\begin{array}{l}-.9442^{* * * *} \\
(.3357)\end{array}$ & $\begin{array}{l}-.6357^{* *} \\
(.2681)\end{array}$ \\
\hline inidevelopment $_{i}$ & $\begin{array}{l}-.3455^{* *} \\
(.1458)\end{array}$ & $\begin{array}{l}-.2685^{*} \\
(.1417)\end{array}$ & $\begin{array}{l}-.2421 \\
(.1717)\end{array}$ & & & \\
\hline domcredit $_{i, t}$ & $\begin{array}{l}-.0060 \\
(.0067)\end{array}$ & $\begin{array}{l}-.0049 \\
(.0047)\end{array}$ & $\begin{array}{l}-.0048 \\
(.0049)\end{array}$ & $\begin{array}{l}-.0148 \\
(.0247)\end{array}$ & $\begin{array}{l}-.0337 \\
(.0351)\end{array}$ & $\begin{array}{l}-.0115 \\
(.0231)\end{array}$ \\
\hline smturnover $_{i, t}$ & $\begin{array}{l}-.0008 \\
(.0021)\end{array}$ & $\begin{array}{l}-.0009 \\
(.0018)\end{array}$ & $\begin{array}{l}-.0011 \\
(.0019)\end{array}$ & $\begin{array}{l}.0004 \\
(.0113)\end{array}$ & $\begin{array}{l}.0247^{*} \\
(.0141)\end{array}$ & $\begin{array}{l}.0182^{*} \\
(.0097)\end{array}$ \\
\hline intasall $_{i, t}$ & $\begin{array}{l}-.3573^{* *} \\
(.1422)\end{array}$ & $\begin{array}{l}-.3095^{* *} \\
(.1268)\end{array}$ & $\begin{array}{l}-.3516^{* *} \\
(.1409)\end{array}$ & $\begin{array}{l}-.3432 \\
(.2757)\end{array}$ & $\begin{array}{l}-.6546^{* * *} \\
(.2073)\end{array}$ & $\begin{array}{c}-1.1556^{* * *} \\
(.1674)\end{array}$ \\
\hline peneta $_{i, t}$ & $\begin{array}{l}-.0064 \\
(.0117)\end{array}$ & $\begin{array}{l}-.0109 \\
(.0106)\end{array}$ & $\begin{array}{l}-.0180 \\
(.0191)\end{array}$ & $\begin{array}{l}.0115 \\
(.0238)\end{array}$ & $\begin{array}{l}-.0142 \\
(.0260)\end{array}$ & $\begin{array}{c}-.0902^{* * *} \\
(.0327)\end{array}$ \\
\hline $\begin{array}{l}\text { intasall }_{i, t} * g r \\
\left(\text { fixed capital }_{i, t}\right.\end{array}$ & & $\begin{array}{l}-.0191^{* * * *} \\
(.0048)\end{array}$ & $\begin{array}{l}-.0192^{* * *} \\
(.0048)\end{array}$ & & $\begin{array}{l}-.0129^{*} \\
(.0075)\end{array}$ & $\begin{array}{l}-.0181^{* * *} \\
(.0055)\end{array}$ \\
\hline intasall $_{i, t} * \operatorname{gr}(\text { labor })_{i, t}$ & & $\begin{array}{l}-.0134 \\
(.0399)\end{array}$ & $\begin{array}{l}-.0216 \\
(.0537)\end{array}$ & & $\begin{array}{l}.2034^{* * *} \\
(.0578)\end{array}$ & $\begin{array}{l}.1226^{* *} \\
(.0462)\end{array}$ \\
\hline $\begin{array}{l}\text { peneta }_{i, t} * g r \\
\left(\text { fixed capital }_{i, t}\right.\end{array}$ & & $\begin{array}{l}.0010^{* *} \\
(.0004)\end{array}$ & $\begin{array}{l}.0009^{* *} \\
(.0004)\end{array}$ & & $\begin{array}{l}.0020^{*} \\
(.0011)\end{array}$ & $\begin{array}{l}.0008 \\
(.0010)\end{array}$ \\
\hline peneta $_{i, t} * \operatorname{gr}(\text { labor })_{i, t}$ & & $\begin{array}{l}-.0034 \\
(.0027)\end{array}$ & $\begin{array}{l}-.0040 \\
(.0037)\end{array}$ & & $\begin{array}{l}.0009 \\
(.0079)\end{array}$ & $\begin{array}{l}.0013 \\
(.0065)\end{array}$ \\
\hline peneta $_{i, t} *$ intasall $_{i, t}$ & & & $\begin{array}{l}.0018 \\
(.0055)\end{array}$ & & & $\begin{array}{l}.0242^{* *} \\
(.0091)\end{array}$ \\
\hline Constant & $\begin{array}{l}5.4707^{* * *} \\
(1.7390)\end{array}$ & $\begin{array}{l}5.3646^{* * *} \\
(1.4290)\end{array}$ & $\begin{array}{l}5.5834^{* * *} \\
(1.2464)\end{array}$ & $\begin{array}{l}4.0514^{* *} \\
(1.9391)\end{array}$ & $\begin{array}{l}7.2621^{* * *} \\
(2.3592)\end{array}$ & $\begin{array}{l}7.2371^{* * *} \\
(1.7797)\end{array}$ \\
\hline Controls & Yes & Yes & Yes & Yes & Yes & Yes \\
\hline Number of observations & 60 & 60 & 60 & 60 & 60 & 60 \\
\hline $\mathrm{R}^{2}$ & 0.769 & 0.811 & 0.811 & 0.814 & 0.892 & 0.928 \\
\hline
\end{tabular}

Notes: gr(fixed capital $)_{i, t}$ represents the growth rate of fixed capital formation. $g r(\text { labor })_{i, t}$ is the growth rate of employed labor. inidevelopment $t_{i}$ represents the initial development level measured by real GDP per capita in the year 1995 in each economy. domcredit $t_{i, t}$ represents the ratio of domestic credit to GDP. smturnover $_{i, t}$ is the stock market turnover rate. intasall $_{i, t}$ is the proxy for competition in banking sector, represented by the ratio of net interest revenue over average assets for all banks. peneta $a_{i, t}$ is the penetration level measured by the assets of foreign banks over total banking sector assets. Control variables include inflation, host country currency depreciation, and the ratio of assets of state-owned banks over total banking sector assets. Robust standard deviations are reported in the parentheses. ${ }^{* * *}$ represents the $1 \%$ significance level, ${ }^{* *} 5 \%$ significance level, and ${ }^{*} 10 \%$ significance level. 
proposition of the Solow growth model. The coefficient on $\operatorname{gr}(\text { labor })_{i, t}$ is negative, suggesting the economic growth in our sample of emerging economies are associated with a reduction in the growth rate of employed labor force. This is consistent with the widely-observed substitution effect between capital and labor in the emerging economies. The coefficient on the initial development level, inidevelopment $t_{i}$, is shown to be negative and statistically significant in the pooled OLS model, which is consistent with the catching up and convergence of economic growth across countries.

The financial sector variables provide only limited evidence for a significant relationship between finance and economic growth. The coefficient on domcredit $t_{i, t}$ is not statistically significant, and the variable of stock market turnover rates, smturnover $_{i, t}$, shows to be a positive and statistically significant coefficient only in the fixed-effects model estimation. The latter is consistent with Levine and Zervos (1998) in that an active stock market is positively associated with economic growth. Other macroeconomic control variables of inflation and foreign exchange depreciation are shown to have statistically insignificant or mixed sign coefficients. $^{13}$

We then discuss the impact of banking competition on economic growth. The coefficient on (the inverse of) the banking competition variable, intasall $_{i, t}$, has a negative sign and is statistically significant in the both models. This implies that a higher competitiveness in the banking sector is associated with a higher economic growth. When the banking sector becomes competitive, the cost of external financing for firms could be lowered, and it fosters output growth to be higher. This result is consistent with Claessens and Laeven (2005). The coefficient on the interaction term of the banking competition with gross fixed capital formation, intasall $_{i, t}{ }^{*}$ gr(fixed capital $)_{i, t}$, is negative and statistically significant. This suggests that the contribution of capital accumulation to economic growth would be higher in a country with a more competitive banking sector than in a country with a less competitive one. However, the interaction term of the banking competition with labor, intasall ${ }_{i, t}^{*}$ gr(labor) $)_{i, t}$, is shown to have either positively signed or statistically insignificant coefficient in the estimations. The positive sign of the coefficient of the labor interaction term might be interpreted that the substitution of labor with capital for economic growth would be higher in a more competitive banking

\footnotetext{
${ }^{13}$ Since inflation and foreign exchange depreciation rate are highly correlated, we have tried to drop either one of them. The results are not changed qualitatively, and the estimated coefficients are only little changed. To save space, we do not report the detailed estimation results on control variables here.
} 
environment than in a less competitive one. ${ }^{14}$

Now we proceed to the discussion on the empirical results related to foreign bank penetration, competition and resource allocation. We find that the coefficient on foreign bank penetration, peneta $_{i, t}$, is not statistically significant in most of alternative specifications or even negatively significant in one of the fixed-effects model estimation. It appears that foreign banks do not exert a robust positive impact on economic growth of the host country. However, after controlling for the effects of banking competition on resource allocation, the interaction term between foreign bank penetration and gross fixed capital formation, peneta ${ }_{i, t}{ }^{*}$ gr (fixed capital $_{i, t}$, is shown to have a positive and statistically significant coefficient. This result indicates that the effect of gross fixed capital formation on output growth is higher in an economy with a more pronounced foreign bank penetration than in an economy with a lower foreign bank penetration. Since banks could channel capital to more productive firms and sectors through their lending decisions, this can be interpreted as evidence that a higher foreign bank penetration would induce the allocation of capital in a more productive way for economic growth. To the contrary, the coefficient on the interaction of foreign bank penetration with labor, peneta $_{i, t}{ }^{*}$ gr(labor $)_{i, t}$, is not statistically significant with mixed signs, implying that the effect of labor on GDP growth is not different across countries with different levels of foreign bank penetration in the emerging economies that are examined in this study. The coefficient on the interaction of foreign bank penetration with banking competition is not statistically significant (pooled OLS estimation) or positive and significant (fixed-effects estimation), implying that foreign banks seem to have limited capacity to enhance banking competition in host countries.

These results suggest that foreign banks play a positive role in enhancing economic growth through the channel of resource allocations, especially physical capital. Foreign banks assume an additional role in allocating capital in a more productive way and enhancing economic growth. This finding is consistent with the hypothetical "direct effect," which was defined and discussed by DemirgucKunt et al. (1998). The "direct effects" are derived from foreign banks' better expertise, know-how and experiences to identify potentially better borrowers and industry sectors, monitor loans more effectively, and establish corporate governance for efficient loan decisions. These direct effects provides various plausible reasons for the channel of resource allocations through which foreign

\footnotetext{
${ }^{14}$ One of the possible reasons for that is that higher competition would have credit more readily channeled to capital-intensive firms and substitute more labor force for capital.
} 
banks have a positive impact on economic growth of the host country.

How can we quantitatively interpret the effect of foreign bank presence on capital allocation and economic growth? We take, for example, specification (3) for the pooled OSL model in Table 3. In an economy with no foreign bank presence in the banking sector, maintaining other conditions to be constant, a 1 percentage point increase in the growth rate of gross fixed capital formation is associated with an increase in the growth rate of GDP per capita of around 0.25 percentage points. If foreign bank penetration increases by 10 percentage points, it would increase the GDP per capita by an additional 0.01 percentage points. If the economy is characterized with the average level of foreign bank penetration in its banking sector, which is 36.9 percent, based on total assets, in our sample, the total increase in the growth rate of GDP per capita due to one percentage point increase in the growth of fixed capital and the presence of foreign banks would be 0.28 percentage points. ${ }^{15}$ It is worthwhile to note that although the effect of foreign bank penetration on the allocation of capital resources is statistically significant, it is relatively small. This finding suggests that the benefits of foreign bank penetration on long-run economic growth in emerging economies should not be overstated.

\section{Robustness Checks}

To check the robustness of the empirical results of both the pooled OLS model and the fixed-effects model, we reestimate the two models using various alternative measures of the variables and a different set of explanatory variables. We first use two alternative measures of the level of foreign bank penetration. The first alternative measure is obtained by calculating foreign banks' share of loans in total loans in the banking sector in a given country and year, and the second measure is borrowed from Micco et al. (2004). The results are reported in Table 4. The new results are qualitatively similar to the results from the benchmark estimation, reported in Table 3. In particular, the coefficient on the interaction term, peneta ${ }_{i, t}{ }^{*}$ gr (fixed capital $_{i, t}$, in both estimations are close to the coefficients estimated using the initial series of the variables. The coefficients are statistically significant with the expected sign in all the fixed-effects estimations and only narrowly insignificant in one of the pooled OLS estimations.

We also use two alternative measures for competition in the banking sector (see Table 5): the ratio of weighted net interest revenue to average assets only for

${ }^{15}$ More specifically, $0.25+0.0009 \times 36.9=0.28$ percentage point. 
Table 4. Robust Test I: Using Alternative Measures of the Foreign Bank Penetration Level

\begin{tabular}{|c|c|c|c|c|}
\hline \multicolumn{5}{|c|}{ Dependent Variable: $g r(G D P \text { per capita })_{i, t}$} \\
\hline & \multicolumn{2}{|c|}{ Pooled OLS } & \multicolumn{2}{|c|}{ Fixed-effects Estimation } \\
\hline & $(1)$ & (2) & (3) & (4) \\
\hline $\operatorname{gr}\left(\right.$ fixed capital $_{i, t}$ & $\begin{array}{l}.2409^{* * *} \\
(.0330)\end{array}$ & $\begin{array}{l}.2371^{* * *} \\
(.0349)\end{array}$ & $\begin{array}{l}.1544^{* *} \\
(.0708)\end{array}$ & $\begin{array}{l}.2202^{* * *} \\
(.0580)\end{array}$ \\
\hline $\operatorname{gr}(\text { labor })_{i, t}$ & $\begin{array}{l}-.1596 \\
(.2169)\end{array}$ & $\begin{array}{l}-.1921 \\
(.2850)\end{array}$ & $\begin{array}{l}-.9586^{* * *} \\
(.3119)\end{array}$ & $\begin{array}{l}-.6678 \\
(.4115)\end{array}$ \\
\hline inidevelopment $_{i}$ & $\begin{array}{l}-.2917^{* *} \\
(.1406)\end{array}$ & $\begin{array}{l}-.5025^{* * *} \\
(.1783)\end{array}$ & & \\
\hline domcredit $_{i, t}$ & $\begin{array}{l}-.0042 \\
(.0048)\end{array}$ & $\begin{array}{l}-.0045 \\
(.0055)\end{array}$ & $\begin{array}{l}-.0405 \\
(.0348)\end{array}$ & $\begin{array}{l}.0025 \\
(.0209)\end{array}$ \\
\hline smturnover $_{i, t}$ & $\begin{array}{l}-.0009 \\
(.0019)\end{array}$ & $\begin{array}{l}.0035^{* *} \\
(.0016)\end{array}$ & $\begin{array}{l}.0269^{*} \\
(.0134)\end{array}$ & $\begin{array}{c}.0122 \\
(.0114)\end{array}$ \\
\hline intasall $_{i, t}$ & $\begin{array}{l}-.3095^{* *} \\
(.1332)\end{array}$ & $\begin{array}{l}-.3336^{* * *} \\
(.1154)\end{array}$ & $\begin{array}{l}-.6689^{* * *} \\
(.2014)\end{array}$ & $\begin{array}{c}-.8538^{* * *} \\
(.2159)\end{array}$ \\
\hline peneta $_{i, t}$ & $\begin{array}{l}-.0082 \\
(.0104)\end{array}$ & $\begin{array}{l}.0000 \\
(.0148)\end{array}$ & $\begin{array}{l}-.0120 \\
(.0224)\end{array}$ & $\begin{array}{c}.0169 \\
(.0232)\end{array}$ \\
\hline $\begin{array}{l}\text { intasall }_{i, t} * \text { gr(fixed capi- } \\
\text { tal }_{i, t}\end{array}$ & $\begin{array}{l}-.0188^{* * *} \\
(.0051)\end{array}$ & $\begin{array}{l}-.0167^{* * *} \\
(.0047)\end{array}$ & $\begin{array}{l}-.0120 \\
(.0074)\end{array}$ & $\begin{array}{l}-.0181^{* *} \\
(.0073)\end{array}$ \\
\hline intasall $_{i, t} * \operatorname{gr}(\text { labor })_{i, t}$ & $\begin{array}{l}-.0134 \\
(.0389)\end{array}$ & $\begin{array}{l}-.0199 \\
(.0408)\end{array}$ & $\begin{array}{l}.2079^{* * *} \\
(.0557)\end{array}$ & $\begin{array}{l}.1139^{* *} \\
(.0510)\end{array}$ \\
\hline $\begin{array}{l}\text { peneta }_{i, t} * \text { gr(fixed capi- } \\
\text { tal }_{i, t}\end{array}$ & $\begin{array}{l}.0011^{* *} \\
(.0004)\end{array}$ & $\begin{array}{l}.0009 \\
(.0005)\end{array}$ & $\begin{array}{l}.0021^{*} \\
(.0011)\end{array}$ & $\begin{array}{l}.0023^{* *} \\
(.0011)\end{array}$ \\
\hline peneta $_{i, t} * \operatorname{gr}(\text { labor })_{i, t}$ & $\begin{array}{l}-.0030 \\
(.0030)\end{array}$ & $\begin{array}{l}-.0005 \\
(.0039)\end{array}$ & $\begin{array}{c}.0011 \\
(.0071)\end{array}$ & $\begin{array}{l}-.0016 \\
(.0058)\end{array}$ \\
\hline Constant & $\begin{array}{l}5.1330^{* * *} \\
(1.4457)\end{array}$ & $\begin{array}{l}4.7507^{* * *} \\
(1.6365)\end{array}$ & $\begin{array}{l}7.4064^{* * *} \\
(2.2201)\end{array}$ & $\begin{array}{l}4.7906^{* *} \\
(2.0856)\end{array}$ \\
\hline Controls & Yes & Yes & Yes & Yes \\
\hline Number of observations & 60 & 58 & 60 & 58 \\
\hline $\mathrm{R}^{2}$ & 0.810 & 0.840 & 0.895 & 0.918 \\
\hline
\end{tabular}

Notes: $g r\left(\text { fixed }_{\text {capital }}\right)_{i, t}$ represents the growth rate of fixed capital. gr(labor $)_{i, t}$ is the growth rate of employed labor. inidevelopment $t_{i}$ represents the initial development level. domcredit $t_{i, t}$ represents the ratio of domestic credit to GDP. smturnover $r_{i, t}$ is the stock market turnover rate. intasall $l_{i, t}$ is the proxy for competition in banking sector, represented by the ratio of net interest revenue over average assets for all banks. peneta $_{i, t}$ is the penetration level measured by the assets of foreign banks over total banking sector assets. Control variables include inflation, host country currency depreciation, and the ratio of assets of state-owned banks over total banking sector assets. In specification (1) and (3), foreign bank penetration level, peneta $\mathrm{i}_{\mathrm{i}, \mathrm{t}}$, is measured in terms of total loans. In (2) and (4), foreign bank penetration level series is borrowed from Micco et al (2004). Robust standard deviation in parenthesis. ${ }^{* * *}$ represents the $1 \%$ significance level, ${ }^{* *} 5 \%$ significance level and ${ }^{*} 10 \%$ significance level. 
Table 5. Robust Test II: Using Alternative Measures of Banking Competition and Banking Sector Development

\begin{tabular}{|c|c|c|c|c|c|c|}
\hline \multicolumn{7}{|c|}{ Dependent Variable: $g r(\text { GDP per capita })_{i, t}$} \\
\hline & & ooled OLS & & & fects Estin & ion \\
\hline & (1) & (2) & (3) & (4) & (5) & (6) \\
\hline & $.2292^{* * *}$ & $.1787^{* * *}$ & $.2641^{* * *}$ & $.1557^{* * *}$ & $.1168^{* *}$ & .1249 \\
\hline gr(juxea (apual) & $(.0310)$ & $(.0551)$ & $(.0579)$ & $(.0800)$ & $(.0518)$ & $(.1004)$ \\
\hline or(labor) & -.1060 & $-.3558^{* * *}$ & $-.6042^{*}$ & -.4901 & $-.4582^{* *}$ & $-1.2854^{* *}$ \\
\hline $\left.\operatorname{gr}_{\text {labor }}\right)_{i, t}$ & $(.2212)$ & $(.1150)$ & $(.3340)$ & $(.3859)$ & (.1964) & $(.6161)$ \\
\hline inidevelopment $_{i}$ & $\begin{array}{l}-.2758^{*} \\
(1457)\end{array}$ & $\begin{array}{l}-.4268 \\
(2740)\end{array}$ & $\begin{array}{l}.0359 \\
(2403)\end{array}$ & & & \\
\hline domcredit $_{i, t}$ & $\begin{array}{l}-.0056 \\
(.0048)\end{array}$ & $\begin{array}{l}-.0070 \\
.0049)\end{array}$ & & $\begin{array}{l}-.0200 \\
(0371)\end{array}$ & $\begin{array}{l}-.0299 \\
(0255)\end{array}$ & \\
\hline credittoprivate $_{i, t}$ & & & $\begin{array}{l}-.0202^{*} \\
(.0110)\end{array}$ & & & $\begin{array}{l}-.0377 \\
(.0306)\end{array}$ \\
\hline smturnover $_{i, t}$ & $\begin{array}{l}-.0010 \\
(.0019)\end{array}$ & $\begin{array}{l}-.0009 \\
(.0020)\end{array}$ & $\begin{array}{l}-.0005 \\
(.0021)\end{array}$ & $\begin{array}{l}.0128 \\
(.0143)\end{array}$ & $\begin{array}{l}.0040 \\
(.0118)\end{array}$ & $\begin{array}{l}.0262^{*} \\
(.0135)\end{array}$ \\
\hline intasall $_{i, t}$ & $\begin{array}{l}-.2870^{* *} \\
(.1187)\end{array}$ & $\begin{array}{l}-.2527^{* *} \\
(.0989)\end{array}$ & $\begin{array}{l}-.4092^{* * *} \\
(.1434)\end{array}$ & $\begin{array}{l}-.5215^{* *} \\
(.1962)\end{array}$ & $\begin{array}{c}-.6449^{* * *} \\
(.1175)\end{array}$ & $\begin{array}{l}-.7405^{* * *} \\
(.2714)\end{array}$ \\
\hline & -.0081 & -.0090 & -.0130 & -.0257 & -.0237 & -.0261 \\
\hline peneicitit & $(.0113)$ & $(.0142)$ & $(.0099)$ & $(.0298)$ & $(.0226)$ & $(.0304)$ \\
\hline peneta $_{i, t} *$ gr(fixed & $.0009^{* *}$ & .0004 & .0009 & $.0022^{*}$ & .0008 & $.0023^{* *}$ \\
\hline $\begin{array}{l}\text { (apital }_{i, t} \\
\text { peneta }_{i, t} *\end{array}$ & $(.0004)$ & $(.0007)$ & $(.0005)$ & $(.0012)$ & $(.0010)$ & $(.0011)$ \\
\hline $\begin{array}{l}\text { peneta }_{i, t}{ }^{*} \\
\text { gr(labor }_{i, t}\end{array}$ & -.0043 & $\begin{array}{l}-.0056 \\
(0046)\end{array}$ & $\begin{array}{l}-.0009 \\
(0033)\end{array}$ & $\begin{array}{l}-.0044 \\
(0083)\end{array}$ & $\begin{array}{l}-.0024 \\
(0069)\end{array}$ & $\begin{array}{l}.0020 \\
(0085)\end{array}$ \\
\hline $\begin{array}{l}\operatorname{gr}_{\text {(labor }}{ }_{i, t} \\
\text { intasall }_{i, t}\end{array}$ & $\begin{array}{l}(.0050) \\
-.0163^{* * * *}\end{array}$ & $\begin{array}{l}.0046) \\
-.0035\end{array}$ & $\begin{array}{l}(.0053)^{* * *} \\
-.0197^{* *}\end{array}$ & $\begin{array}{l}(.0083) \\
-.0144^{* *}\end{array}$ & $\begin{array}{l}(.0069) \\
-.0058\end{array}$ & $\begin{array}{l}(.0085) \\
-.0103\end{array}$ \\
\hline $\operatorname{gr}\left({\text { fixed capital })_{i, t}}_{1}\right.$ & $(.0041)$ & $(.0051)$ & $(.0067)$ & $(.0068)$ & $(.0041)$ & $(.0098)$ \\
\hline intasall $_{i, t} *$ & -.0177 & .0316 & .0177 & $.1238^{*}$ & $.1250^{* * *}$ & $.2325^{* * *}$ \\
\hline $\operatorname{gr}(\text { labor })_{i, t}$ & $(.0399)$ & $(.0148)$ & $(.0388)$ & $(.0639)$ & $(.0200)$ & $(.0661)$ \\
\hline credittoprivate $_{i, t}$ * & & & -.0005 & & & .0000 \\
\hline $\operatorname{gr}\left({\text { fixed capital })_{i, t}}_{\text {. }}\right.$ & & & $(.0004)$ & & & $(.0007)$ \\
\hline $\begin{array}{l}\text { credittoprivate }_{i, t} \text { * } \\
{\text { gr(labor })_{i t}}\end{array}$ & & & .0061 & & & .0045 \\
\hline $\operatorname{gr}(\text { labor })_{i, t}$ & & & $(.0037)$ & & & $(.0067)$ \\
\hline Constant & $5.2938^{* * *}$ & $5.7136^{* * *}$ & $6.3452^{* * *}$ & $\begin{array}{l}7.5745^{* * *} \\
(07582)\end{array}$ & $9.4115^{* * *}$ & $8.0356^{* * *}$ \\
\hline Controls & Yes & Yes & Yes & Yes & Yes & $\begin{array}{c}(2 .+0 J) \\
\text { Yes }\end{array}$ \\
\hline Obs & 60 & 60 & 60 & 60 & 60 & 60 \\
\hline $\mathrm{R}^{2}$ & 0.809 & 0.758 & 0.818 & 0.875 & 0.902 & 0.893 \\
\hline
\end{tabular}

Notes: gr(fixed capital) $)_{i, t}$ represents the growth rate of fixed capital. gr(labor $)_{i, t}$ is the growth rate of employed labor. inidevelopment ${ }_{i}$ represents the initial development level. domcredit ${ }_{i, t}$ represents the ratio of domestic credit to GDP. credittoprivate $i_{i, t}$ is the ratio of banking sector credit only to the private sector to GDP. smturnover $r_{i, t}$ is the stock market turnover rate. peneta $a_{i, t}$ is the penetration level measured by the assets of foreign banks over total banking sector assets. Control variables include inflation, host country currency depreciation, and the ratio of assets of state-owned banks over total banking sector assets. In specification (1) and (4), the competition level of banking sector, intasall $l_{i, t}$, is measured by the net interest revenue over average assets for only domestic banks; in (2) and (5), measured by the non-interest expenses over average assets for all banks; in (3) and (6), measured by net interest revenue over average assets for all banks. ${ }^{* * *}$ represents the $1 \%$ significance level, ${ }^{* *} 5 \%$ significance level and ${ }^{*} 10 \%$ significance level. 
domestic banks instead of all banks ( niraadom $_{i, t}$ ) and the ratio of weighted noninterest expenses to average assets for all banks (nieaaall $\left.{ }_{i, t}\right)$. The coefficients on the interaction term, peneta $_{i, t}{ }^{*}$ gr(fixed capital $)_{i, t}$, remain the same qualitatively, but they are statistically significant only when we use niraadom $_{i, t}$ as the banking competition measure. The reason might be that non-interest expenses partially reflect the average management quality in the host country banking sector, which undermines its explanatory power as a proxy of competition level. We also use the banking concentration rate, which is the three largest banks' share of assets in the banking sector total assets, to measure the degree of competition in the banking sector, since a more concentrated banking market would be less competitive than otherwise. However, the statistical significance of the interaction terms between foreign bank penetration and competition with resource allocation disappears. The reason could be that the concentration rate is not necessarily a good measure of the competition level. The correlation between concentration rate and all other competitiveness measures is very small (less than 0.1 ), but it is relatively large with foreign bank penetration level (more than 0.21). ${ }^{16}$

Finally, we check the robustness of our estimates by replacing domcredit $t_{i, t}$ with credittoprivate $_{i, t}$, the ratio of the banking sector credit only to the private sector to GDP, which, as many researchers argue, could be a better measure of banking sector development. (For example, see Levine and Zervos (1998) and Beck et al. (2000).) We also interact this measure with gr(fixed capital $)_{i, t}$ and gr(labor $)_{i, t}$ to control for the possibility that the observed effects are actually attributable to advances in banking development. The coefficient on the interaction term, peneta $_{i, t}{ }^{*}$ gr(fixed capital $)_{i, t}$ remains numerically similar and statistically significant in the fixed-effects estimation, and only barely insignificant in the pooled OLS estimation ( $p$-value $=0.114$ ). The effects of competitiveness remain the same, while no significant difference is found in the economies with the different levels of credittoprivate $_{i, t}$.

\section{Conclusion}

In this paper, we examined the relationship between foreign bank penetration and economic growth by focusing on the role of foreign banks in the allocation of resources in the host country. Using the aggregated banking data which we

\footnotetext{
${ }^{16}$ The estimation results are not reported here to save space. They are available from the authors upon request.
} 
constructed from the bank-level balance sheet and income statement data covering a total of 1273 banks in 35 emerging economies from Asia, Latin America, and Central and Eastern Europe during the period from 1996 to 2003, we present evidence that foreign banks play a positive role in enhancing economic growth through the channel of resource allocation in host countries.

After controlling for the impact of the competitiveness in the banking sector on output growth, we found evidence that foreign banks play a significant role in more productive and efficient allocation of capital, if not labor, contributing to economic growth of host countries. A ten percentage point increase in the level of foreign bank penetration would increase the growth rate of GDP per capita by 0.28 percentage points, for each percentage point increase in fixed capital formation, for a country with the mean level of foreign bank penetration in our sample. The evidence is consistent with the proposed "direct effect" of foreign banks, à la Demirguc-Kunt et al. (1998), on economic growth. Plausible types of the direct effects include seeking and identifying good borrowers, imposing a more stringent loan monitoring system, and exercising more efficient corporate surveillance for loanable funds, among others.

The main findings of this paper provide useful policy implications for monetary authorities in emerging economies. It is worthwhile for policy makers in emerging economies to try to maximize the spillover effects of foreign bank penetration on economic growth through the channel of resource allocations. Although an increasing level of foreign bank penetration itself may not be able to enhance economic growth, it is shown to contribute to economic growth through banking competition and resource allocation effects. However, the effect of foreign bank penetration on the resource allocation efficiency is relatively small, which suggests that the benefits of foreign bank participation in the host country banking sector should not be overstated.

This paper also provides policy implications on the economic integration of emerging economies. Our findings imply that foreign banks may serve as a channel in enhancing economic integration of emerging economies with advanced economies that are the home countries of foreign banks. The foreign-bank channel of economic integration warrants more thorough analysis.

One of the challenges for our estimation is the short time-series dimension, which limits our choice for econometric methods. The strict exogeneity assumption of the fixed-effects estimation might be violated if there is feedback from GDP growth to regressors. Although the GMM estimation might overcome the 
drawbacks in the fixed-effects estimation, it cannot be conducted thoroughly due to the small number of observations. We leave these challenges for the future research.

\section{Acknowledgement}

The views expressed in this paper are those of the authors only, and do not necessarily represent the views of the IMF. We thank an anonymous referee and the Editor of the Journal for useful comments and suggestions.

Received 1 August 2009, Revised 24 December 2009, Accepted 29 December 2009

\section{Reference}

Arena, M., C. Reinhart, and F. Vázquez(2006), "The Lending Channel in Emerging Economies: are Foreign Banks Different?", Working paper.

Bayraktar, Nihal. and Yan Wang(2006), "Banking Sector Openness and Economic Growth", Working paper.

Beck, Thorsten. Asli Demirgüç-Kunt and Ross Levine(2000), "A New Database on Financial Development and Structure”, World Bank Economic Review 14, 597-605.

Beck, Thorsten, Ross Levine and Norman Loayza(2000), "Finance and the Source of Growth", Journal of Financial Economics, 58, pp 261-300.

Beck, Thorsten, Asli Demirgüç-Kunt and Ross Levine(2004), "Finance, Inequality and Poverty: Cross-Country Evidence", NBER working paper 10979.

Berger, Allen., Leora Klapper and Gregory Udell(2001), "The Ability of Banks to Lend to Informationally Opaque Small Businesses", Journal of Banking and Finance, 25, pp 2127-67.

Claessens, Stijin, Asli Demirguc-Kunt, and Harry Huizinga(2001), "How Does Foreign Entry Affect the Domestic Banking Markets?", Journal of Banking and Finance, 25(5), pp 891 - 911.

Claessens, Stijn and Luc Laeven(2005), "Financial Dependence, Banking Sector Competition and Economic Growth", World Bank Policy Research Working Paper 3481.

Clarke, George R.G., Robert Cull, and Maria Soledad Martinez Peria(2001), "Does Foreign Bank Penetration Reduce Access to Credit in Developing Countries? Evidence from Asking Borrowers", World Bank working paper.

Clarke, George R.G., Robert Cull, Maria S. M. Peria, and Susana M Sanchez(2002), "Bank Lending to Small Businesses in Latin America: Does Bank Origin Matter?", working paper.

Crystal, Jennifer, B.G. Dages and L.S. Goldberg(2002), "Has Foreign Bank Entry Led To 
Sounder Banks in Latin America?", Federal Reserve Bank of New York, Current Issues in Economics and Finance, 8(1).

De Gregorio, Jose and Pablo Guidotti(1995), "Financial Development and Econoic Growth", World Development, 23(3), pp 433-48.

Demirguc-Kunt, Asli., Ross Levine and Hong-Ghi Min(1998) "Opening to Foreign Banks: Issues of Stability, Efficiency and Growth", The Implications of Globalization of World Financial Markets: Conference Proceedings, pp. 83-105.

Detragiache, Enrica, Poonam Gupta and Thierry Tressel(2006), "Foreign Banks in Poor Countries: Theory and Evidence", Working paper.

Giannetti, Mariassunta and Steven Ongena(2007), "Financial Integration and Firm Performance: Evidence from Foreign Bank Entry in Emerging Markets", Working paper.

Goldberg, Linda, Gerard Dages and Daniel Kinney(2000), "Foreign and Domestic Bank Participation in Emerging Markets: Lessons from Argentina and Mexico", Working paper.

Goldberg, Linda, Gerard Dages and Daniel Kinney(2001), "When is U.S. Lending to Emerging Market Volatile", Federal Reserve Bank of New York, March.

Goldsmith, Raymond.(1969) Financial Structure and Development, Yale University Press.

Gormley, Todd.(2007), "Banking Competition in Developing Countries: Foreign Bank Entry Improve Credit Access?", Working paper.

Kashyap, A. and J. Stein(2000), "What Do a Million Observations on Banks Say About the Transmission of Monetary Policy", American Economic Review, Vol.90, pp.407428.

Kishan, R. and T. Opiela(2000), "Bank Size, Bank Capital and Bank Lending Channel", Journal of Money, Credit and Banking, Vol.32, pp.121-141.

King, Robert and Ross Levine(1993a) "Finance and Growth: Schumpeter Might Be Right", Quarterly Journal of Economics, 108(3), pp 717-38.

King, Robert and Ross Levine(1993b) "Finance, Entrepreneurship, and Growth: Theory and Evidence", Journal of Monetary Economics, 32(3), pp 513-42.

Levine, Ross.(1996), "Financial Development and Economic Growth: Views and Agenda", World Bank, Policy Research Working Paper 1678.

Levine, Ross, Norman Loayza and Thorsten Beck(2000), "Financial Intermediation and Growth: Causality and Causes", Journal of Monetary Economics, 46, pp 31-77.

Levine, Ross and Sara Zervos(1998), "Stock Markets, Banks and Economic Growth", American Economic Review, 88(3), pp 537-58.

Lucas, Robert.(1988) "On the Mechanics of Economic Development", Journal of Monetary Economics, 22(1), pp 3-42.

Martinez Peria, Maria Soledad and Ashoka Mody(2004), "How Foreign Participation and Market Concentration Impact Bank Spreads: Evidence from Latin America", Journal of Money Credit and Banking, 36(3), pp 511-37.

Micco, Panizza and Yanez(2004) "Bank Ownership and Performance", IDB-RES working 
paper No. 518.

Peek, Joe. and Eric. Rosengren(2000), "Collateral Damage: Effects of the Japanese Bank Crisis on Real Activity in the United States", American Economic Review, 90(1), pp 30-45.

Rajan, Raghuram and Luigi Zingales(1998), "Financial Dependence and Growth", American Economic Review, 88(3), pp 559-86. 